\title{
Estimasi Ukuran Populasi Efektif Sapi Bali Berdasarkan Data Genom
}

\section{(Estimation of Effective Population Size for Bali Cattle Based on Genomic Data)}

\author{
Sudrajad $\mathrm{P}^{1}$, Volkandari $\mathrm{SD}^{2}$, Prasetyo $\mathrm{D}^{3}$, Cahyadi $\mathrm{M}^{4}$, Pujianto $\mathrm{J}^{3}$, Subiharta ${ }^{1}$ \\ ${ }^{1}$ Balai Pengkajian Teknologi Pertanian Jawa Tengah \\ ${ }^{2}$ Pusat Penelitian Bioteknologi LIPI, Cibinong, Bogor \\ ${ }^{3}$ Balai Pembibitan Ternak Unggul Sapi Bali, Pulukan, Bali \\ ${ }^{4}$ Fakultas Pertanian Universitas Sebelas Maret, Surakarta \\ psudrajad@litbang.pertanian.go.id
}

\begin{abstract}
Bali cattle (Bos javanicus) is a local cattle and native to Indonesia, which currently has a population of 32.3\% nationally. Efforts to develop Bali cattle in Indonesia have gone through a long history that allows an influence on their genetic status. This study aimed to identify the status of Bali cattle genetic diversity in terms of effective population size $\left(N_{e}\right)$ by utilizing genomic technology. The genome data used amounted to 48 samples from the DNA of 48 Bali cattle in BPTU - Denpasar, which were processed using Illumina Bovine SNP50 v3 beadchip. Data quality control with PLINK software and $N_{e}$ estimation was calculated using R software. From the analysis it was found that from 53,218 SNPs, the average callrate was $97.8 \%$. The $N_{e}$ value of the Bali cattle population has experienced a very sharp decline and has risen again since 40 generations ago. At present, the $N_{e}$ value of Bali cattle was 151, greater than the minimum value required by FAO so that a population was protected from extinction. Efforts and support from various parties are needed to maintain the diversity status of Bali cattle.
\end{abstract}

Key words: Effective population size, Bali cattle, genome

\begin{abstract}
ABSTRAK
Sapi Bali (Bos javanicus) merupakan sapi lokal yang asli Indonesia, yang saat ini populasinya mencapai 32,3\% secara nasional. Upaya pengembangan sapi Bali di Indonesia telah melewati sejarah panjang yang memungkinkan terjadinya pengaruh terhadap status genetiknya. Penelitian ini bertujuan untuk mengidentifikasi status keragaman genetik sapi Bali dari sisi ukuran populasi efektif $\left(N_{e}\right)$ dengan memanfaatkan teknologi genom. Data genom yang digunakan berjumlah 48 sampel yang berasal dari DNA 48 ekor sapi Bali di BPTU sapi Bali Denpasar yang diproses dengan menggunakan Illumina Bovine SNP50 v3 beadchip. Kontrol kualitas data dengan software PLINK dan estimasi $N_{e}$ dikalkulasikan dengan menggunakan software R. Dari analisis diketahui bahwa dari 53.218 SNP pada beadchip, ratarata callrate sebesar $97,8 \%$. Nilai $N_{e}$ populasi sapi Bali pernah mengalami penurunan yang sangat tajam dan naik kembali sejak 40 generasi yang lalu. Pada masa sekarang ini nilai $N_{e}$ sapi Bali sebesar 151, lebih besar dari nilai minimum yang dipersyaratkan FAO agar suatu populasi terhindar dari kepunahan. Perlu upaya dan dukungan dari semua pihak guna mempertahankan status keragaman sapi Bali.
\end{abstract}

Kata kunci: Ukuran populasi efektif, sapi Bali, genom 


\section{PENDAHULUAN}

Sapi Bali (Bos javanicus) apabila ditinjau dari kajian sejarah dan genetik, merupakan sapi lokal yang asli Indonesia (Mohamad et al. 2009; Sutarno \& Setyawan 2016). Sapi ini merupakan keturunan Banteng yang diperkirakan proses domestikasinya berlangsung lebih dari 2.000 tahun yang lalu. Sapi Bali disebut sebagai sapi yang paling cocok untuk dibudidayakan di berbagai daerah di Indonesia, sebab dapat beradaptasi di lingkungan tropis dengan pertumbuhan dan proporsi karkas yang baik walaupun dengan keterbatasan sumber daya pakan. Karakter/sifat inilah yang menjadikan sapi Bali dapat diunggulkan dan digemari oleh peternak. Sehingga berdasarkan hasil sensus disebutkan bahwa sapi Bali merupakan bangsa sapi dengan populasi terbesar di Indonesia, yakni mencapai 32,3\% (Kementan \& BPS 2011).

Upaya pengembangan sapi Bali di Indonesia melewati sejarah yang cukup panjang, mulai dari isolasi sapi Bali di pulau Bali, dibentuknya balai pembibitan, hingga proses penyebarannya ke berbagai wilayah di Indonesia. Tentu saja fase-fase tersebut akan berpengaruh terhadap status genetik sapi Bali saat ini. Selama ini, kajian mengenai struktur genetik dan status demografi sapi Bali, khususnya mengenai ukuran populasi efektifnya belum pernah dilakukan. Memahami mengenai ukuran populasi efektif $\left(N_{e}\right)$ sapi Bali sangat penting sebab upaya mempertahankan status keragaman genetik sapi Bali merupakan salah satu target yang ingin dicapai oleh pemerintah, dalam hal ini Balai Pembibitan Ternak Unggul (BPTU) sapi Bali. Nilai $N_{e}$ yang tinggi mengindikasikan bahwa terdapat variasi genetik yang besar pada populasi ternak tersebut, demikian juga sebaliknya (Sudrajad 2016).

Seiring pesatnya perkembangan teknologi, riset terkait pemanfaatan teknologi molekuler untuk pemuliaan telah masuk ke ranah genom. Genom pada ternak merupakan informasi keseluruhan DNA yang berada dalam sel di tubuh ternak tersebut. Oleh karena itu teknologi genom dipercaya dapat memetakan gen pada tubuh ternak secara lebih tepat (Hocquette et al. 2007). Berbagai metode analisis untuk mengeksplorasi informasi genom saat ini telah berkembang dan dimanfaatkan oleh banyak kalangan, termasuk para peneliti di Indonesia. Informasi genom tersebut juga dapat dimanfaatkan untuk mengestimasikan nilai $N_{e}$ dari suatu populasi.

Penelitian ini merupakan studi pendahuluan guna mengidentifikasi nilai ukuran populasi efektif sapi Bali dengan memanfaatkan data genom. Hasil penelitian ini diharapkan dapat digunakan sebagai dasar penelitian lanjutan mengenai keragaman genetik sapi Bali dan bermanfaat untuk digunakan sebagai bahan evaluasi pengembangan sapi Bali, khususnya di BPTU sapi Bali.

\section{MATERI DAN METODE}

\section{Data genom}

Data genom sapi Bali yang digunakan dalam penelitian ini berjumlah 48 sampel, berasal dari DNA hasil isolasi dari darah 48 ekor sapi Bali yang dibudidayakan di BPTU Denpasar. Isolasi DNA dilaksanakan dengan mengikuti metode Sambrook et al. (1989). Pengecekan konsentrasi DNA dilaksanakan dengan Picogreen (Thermo Fisher Scientific Inc., USA) dan pengecekan kemurnian DNA dilakukan dengan menggunakan NanoDrop (Thermo Fisher Scientific Inc., USA). Sampel DNA dikatakan memenuhi standar kualitas apabila konsentrasi minimal $20 \mathrm{ng} / \mu \mathrm{l}$ dan kemurniannya $>1,5$. Selanjutnya sampel DNA 
diproses dengan menggunakan Illumina Bovine SNP50 v3 Beadchip untuk mendapatkan data genom yang terdiri dari 53.218 SNP.

\section{Kontrol kualitas data genom}

Data genotip harus terlebih dahulu dibersihkan dari data yang memiliki kualitas rendah menggunakan program PLINK v1.07 (Purcell et al. 2007). Kontrol kualitas untuk data genotip menggunakan kriteria sebagai berikut: variasi SNP akan dipertahankan apabila nilai Hardy-Weinberg Equilibrium (HWE) tidak kurang dari 1 x $10^{-4}$, nilai persentase SNP yang ditemui (call rate) lebih besar dari 90\%, frekuensi allel minor kurang dari 1\%, varian SNP kosong dalam setiap individu dan genotip kosong dalam setiap varian tidak boleh lebih dari 10\% (Sudrajad et al. 2016). Selain itu, kromosom yang digunakan adalah kromosom tubuh (autosome) yakni kromosom 1-29.

\section{Estimasi ukuran populasi efektif}

Nilai $N_{e}$ diestimasikan dengan berdasarkan rumus yang telah disampaikan oleh Hayes et al (2003) sebagai berikut:

$$
N_{e}=\frac{1}{4 c} *\left(\frac{1}{r^{2}}-1\right)
$$

Dalam rumus tersebut, simbol $c$ merupakan jarak rekombinasi dalam satuan Morgans. Sedangkan $r^{2}$ merupakan asosiasi non-acak alel-alel pada lokus yang berbeda di dalam suatu populasi, yang dihitung menggunakan rumus yang dijelaskan oleh Sved (1971). Estimasi nilai $N_{e}$ dikalkulasikan dengan menggunakan software R v.3.2.2 (R Core Team 2015).

\section{HASIL DAN PEMBAHASAN}

\section{Kondisi data genom sapi Bali}

Jumlah SNP yang digunakan dalam penelitian ini sebanyak 53.218 varian (Illumina Inc., USA). Berdasarkan data hasil genotyping, rata-rata persentase SNP yang ditemui (call rate) di genom sapi Bali sebesar 97,8\%. Selain itu skor genotip yang ditemui dalam setiap SNP rata-rata sebesar 0,7. Hal ini berarti tingkat realibilitas data SNP dalam penelitian ini tinggi. Secara total, jumlah SNP dari data genom sapi Bali di BPTU Denpasar yang didapatkan setelah proses kontrol kualitas data genom sebanyak 49.439 varian (93\%). Berkurangnya jumlah varian tersebut terutama disebabkan karena beberapa genotip tidak dapat teridentifikasi dengan baik pada saat proses genotyping (Purcell et al. 2007).

\section{Ukuran populasi efektif sapi Bali}

Dalam penelitian ini, terdapat pola yang unik untuk nilai $N_{e}$ pada populasi sapi Bali. Apabila ditinjau dari perubahan nilai ukuran populasi efektif $\left(N_{e}\right)$ dari beberapa generasi yang lalu, dapat diketahui bahwa ukuran populasi efektif sapi Bali pernah mengalami penurunan yang tajam. Namun sejak 40 generasi yang lalu hingga sekarang nilai $N_{e}$ cenderung mengalami kenaikan kembali (Tabel 1). Biasanya, nilai $N_{e}$ suatu populasi cenderung tinggi pada generasi yang lalu dan akan turun secara kontinyu hingga generasi sekarang (Flury et al. 2010; Sudrajad et al. 2016). 
Nilai $N_{e}$ merupakan gambaran dari sebuah pola variasi genetik, sehingga dapat digunakan untuk menjelaskan status keragaman pada suatu populasi saat ini dan di masa lampau (Flury et al. 2010). Oleh karena itu, grafik nilai $N_{e}$ populasi sapi Bali dalam penelitian ini menggambarkan bahwa terdapat upaya untuk meningkatkan variasi genetik sapi Bali sejak 40 generasi yang lalu. Upaya tersebut secara nyata dapat dibuktikan bahwa di Indonesia, pembentukan unit pembibitan sapi Bali (BPTU Sapi Bali) sejak tahun 1976, pelaksanaan penyebaran sapi Bali ke beberapa daerah lain serta upaya seleksi sapi Bali unggul yang pernah digalakkan telah memberikan hasil yang baik guna menjaga keragaman genetik sapi Bali.

Tabel 1. Ukuran populasi efektif sapi Bali dari beberapa generasi

\begin{tabular}{lccccc}
\hline \hline $\begin{array}{l}\text { Generasi yang } \\
\text { lalu }\end{array}$ & $N_{e}$ & $\begin{array}{c}\text { Generasi yang } \\
\text { lalu }\end{array}$ & $N_{e}$ & $\begin{array}{c}\text { Generasi yang } \\
\text { lalu }\end{array}$ & $N_{e}$ \\
\hline 1.482 & 766 & 55 & 132 & 19 & 137 \\
672 & 390 & 40 & 130 & 17 & 148 \\
335 & 262 & 28 & 135 & 15 & 153 \\
127 & 151 & 23 & 136 & 13 & 160 \\
71 & 125 & 21 & 142 & 11 & 151 \\
\hline
\end{tabular}

Nilai $N_{e}$ populasi sapi Bali saat ini masih jauh lebih besar apabila dibandingkan batas minimum yang dipersyaratkan oleh Food and Agricultural Organization (FAO) agar suatu populasi sapi dapat dikatakan jauh dari ancaman kepunahan, yaitu 50 pada setiap generasi (Lu et al. 2012). Upaya yang diperlukan selanjutnya adalah bagaimana mempertahankan status keragaman populasi sapi Bali yang baik tersebut.

\section{KESIMPULAN}

Ukuran populasi efektif sapi Bali sejak 40 generasi yang lalu mengalami kenaikan dan saat ini mencapai nilai 151. Nilai ini lebih besar dari syarat minimal yang ditetapkan FAO. Perlu upaya dan dukungan dari berbagai pihak guna mempertahankan status keragaman genetik sapi Bali.

\section{UCAPAN TERIMA KASIH}

Penulis berterimakasih atas dukungan Program Insentif Riset Sistem Inovasi Nasional (INSINAS) Kementerian Riset Teknologi dan Pendidikan Tinggi Tahun 20182019.

\section{DAFTAR PUSTAKA}

Flury C, Tapio M, Sonstegard T, Drögemüller C, Leeb T, Simianer H, Hanotte O, Rieder S. 2010. Effective population size of an indigenous Swiss cattle breed estimated from linkage disequilibrium. J Anim Breeding Genet. 127:339-347.

Hayes BJ, Visscher PM, McPartlan HC, Goddard ME. 2003. Novel multilocus measure of linkage disequilibrium to estimate past effective population size. Genome Res. 13:635643.

Hocquette JF, Lehnert S, Barendse W, Cassar-Malek I, Picard B. 2007. Recent advances in cattle functional genomics and their application to beef quality. Animal. 1:159-173. 
Kementan dan BPS. 2011. Rilis akhir hasil Pendataan Sapi dan Kerbau (PSPK) 2011. Kerjasama antara Kementerian Pertanian dan Badan Pusat Statistik.

Lu D, Sargolzaei M, Kelly M, Li C, Vander Voort G, Wang Z, Plastow G, Moore S, Miller SP. 2012. Linkage disequilibrium in Angus, Charolais, and Crossbred beef cattle. Frontiers in Genetics. 3:152.

Mohamad K, Olsson M, van Tol HTA, Mikko S, Vlamings BH, et al. 2009. On the origin of Indonesian cattle. PLoS ONE. 4:e5490.

Purcell S, Neale B, Todd-Brown K, Thomas L, Ferreira MAR, Bender D, Maller J, Sklar P, de Bakker PIW, Daly MJ, Sham PC. 2007. PLINK: a toolset for whole-genome association and population-based linkage analysis. Am J Human Genet. 81:559-575.

R Core Team. 2015. R: A language and environment for statistical computing. Vienna (Austria): R Foundation for Statistical Computing.

Sambrook J, Fritsch EF, Maniatis T. 1989. Molecular cloning, a laboratory manual. USA: Cold Spring Harbour Laboratory Press.

Sudrajad P, Seo DW, Choi TJ, Park BH, Roh SH, Jung WY, Lee SS, Lee JH, Kim S, Lee SH. 2016. Genome-wide linkage disequilibrium and past effective population size in three Korean cattle breeds. Anim Genet. 48:85-89.

Sudrajad P. 2016. Genome-wide analysis of diversity, linkage disequilibrium, and effective population size in Korean and Indonesian beef cattle. Thesis. Department of Animal Science and Biotechnology, Faculty of Agriculture and Life Science, Chungnam National University, Korea Selatan.

Sutarno, Setyawan AD. 2016. Review: The diversity of local cattle in Indonesia and the efforts to develop superior indigenous cattle breeds. Biodiversitas. 17:275-295.

Sved JA. 1971. Linkage disequilibrium and homozygosity of chromosome segments in finite populations. Theoritical Population Biology. 2:125-141. 